\title{
Introduction: Stability, Risks and Opposition in Singapore
}

\author{
James Gomez and CAn-Seng OoI (Guest Editors)
}

The respected Political and Economic Risk Consultancy (PERC) Group has consistently assessed Singapore's domestic political risk as low. Since 1997, on a scale of between zero and 10, with zero being the best grade possible and 10 the worst, the city-state's worst grade for domestic political risk was below 3 (PERC 2005). Singapore's scores hover mostly around the 2 mark. PERC partly attributes Singapore's low domestic political risk to the fact that it is 'very difficult for a formal political opposition to unseat the PAP (People's Action Party) from power even if there were a vibrant multi-party system' (PERC 2005).

This observation is shared by Freedom House, an international NGO that publishes an annual report on global trends in democracy: 'Citizens of Singapore cannot change their government democratically' (Freedom House 2005). Political risk is often associated with the threat of potential changes of government that may result in changes in policies that may adversely affect the country's business climate. Political risk is a concern to all countries. Unlike many other countries that boast of their mature and institutionalized democracies that allow for the smooth change of governments without jeopardizing the business climate, the case of Singapore is apparently different. Singapore scores low on political risk because the Singaporean government, under the PAP, sees domestic political opposition as a potential site of instability and has actively taken steps to curtail and contain critics. Paradoxically, Singapore's good rating on the 'political risk' scale might have jeopardized Singapore's democracy. However, what is good for international and domestic business is not necessarily good for civil society.

The Singaporean PAP government has entrenched its dominant political position over a period of some four decades. Efforts continue to be taken to ensure that political activism remains low and managed through controlled channels (George 2000; Koh and Ooi 2000; Mauzy and Milne 2002). Alternative political expressions are often treated as dangerous and are met with efforts to neutralize them to maintain the country's 'stability'. Many PAP critics tread warily when making 
any statements against the PAP because many have suffered the consequences as 'dissidents' (see Gomez in this volume).

As a self-acknowledged soft authoritarian regime, Singapore has become one of the most politically stable and economically competitive countries in the world. The Singaporean model suggests that some elements of democracy must be controlled to maintain the country's stability. So, what are some of these political 'risks' that the ruling PAP is so keen to control? What are the examples of control and how have the strategies evolved over the years? What insights can we gain from examining how the PAP government has responded to domestic critics? Is the inability to effectively challenge PAP policies necessarily a good thing? These concerns are addressed in this special issue of The Copenhagen Journal of Asian Studies.

\section{The Papers in this Collection}

After the rigour of the double-blind peer review process, five papers have been assembled for this collection. They all deal with the management of (in)stabilities in Singapore. The collection begins with Marc Rerceretnam's 'Beyond the Clutches: The 1987 ISA Arrests and International Civil Society Responses to Political Repression in Singapore'. This provides an overview of how the 1987 crackdown on alleged dissidents in Singapore spurred international NGOs and expatriate Singaporean communities to focus attention on human rights abuses in Singapore and mobilize international opinion. We can see that the ISA was an effective tool for dealing with critics, but the PAP government had to pay the price of negative publicity from the international community and media.

In his article, 'Selling Security: The War on Terror and the Internal Security Act of Singapore', Damien Cheong demonstrates how the Singapore government, despite its respect for the rule of law, has been able to justify the use of the long-standing ISA on terrorist suspects. We see here that a new security environment has helped legitimize old laws in dealing with dissenters. We also see the creeping application of sophisticated public relations strategies to manage negative perceptions internationally.

Jonathan Woodier's article, 'Securing Singapore/Managing Perceptions: From Shooting the Messenger to Dodging the Question", shows how the Singaporean government uses public relations in its various social and economic programmes. Singapore is of course not the only 
country that attempts to manage and cultivate public opinions and perceptions. This city-state, however, is in the forefront of this public relations engineering in Asia. The public relations campaigns are complex and driven by the need, first, to persuade and coerce Singaporeans and the rest of the world to regard Singapore as a good place for investment, tourism and residence and, second, to simultaneously project Singapore as a socially and economically vulnerable city-state.

The fourth paper in this collection, by Yan Jin, Augustine Pang and Glen T. Cameron, analyses public perceptions of how the government managed the SARS crisis in 2003. Based on their survey, the paper concludes that the PAP government has been supremely successful in managing the perceptions and emotions of Singapore's residents by building on their ingrained fears of future insecurity.

James Gomez, the author of the final paper in this collection, evaluates the impact of laws that restrict and control the free speech of opposition parties and politicians in Singapore. He demonstrates how the freedom of speech of opposition parties is often restricted because of its potential to cause 'instability'. The struggle for freedom of expression in Singapore needs to recruit new mechanisms to assist opposition politicians. A greater diversity of means also makes it harder for the PAP to keep control of all the news.

The collection of papers presented in this special issue emerged out of the Singapore Studies Project initiated in 2004 at the Monash Asia Institute (Melbourne, Australia).

James Gomez is a Ph.D. candidate at Monash Asia Institute, Monash University, Australia. Can-Seng Ooi is an Associate Professor at Copenhagen Business School.

\section{REFERENCES}

Freedom House 2005. 'Country Report: Singapore'. Available from: http://www. freedomhouse.org/template.cfm?page $=22 \&$ year $=2005$

George, C. 2000. Singapore: the Air-Conditioned Nation. Singapore: Landmark Books.

Koh, Gillian and Ooi Geok Ling 2000. State-Society Relations in Singapore. Singapore: Oxford University Press,.

Mauzy, Diane K. and R. S. Milne 2002. Singapore Politics under the People's Action Party. London: Routledge.

PERC 2005. Singapore Risk Rating Update. Hong Kong: PERC. 